\title{
Emeritus Professor David Henry Marshall, M.A.
}

The passing of this lovable personality awakens a sense of loss among admirers at home and abroad. He had spent a quarter of a century in retirement at his beautiful residence by the shore of Lake Ontario, where he died on Sunday, 13th March 1932.

Son of John Marshall, a Jury Court Macer, David Henry was born at No. 31 Howe Street, Edinburgh, 9th April 1848. Taught for two years by Mr Robert B. Crowe, of the Rev. Dr Andrew Thomson School at No. 10 Queensferry Street, he was nominated for admission to Donaldson's Hospital by a distinguished trio, the Hon. Lord Curriehill, the Rev. Dr Candlish, and Sir William Gibson-Craig, Bart., of Riccarton. A contemporary at Donaldson's, his senior by four years, was Sir Alexander Oliver Riddell, LL.D., proprietor of Craiglockhart. Marshall proceeded later to the University of his own romantic town, where he secured medals in Mathematics and Natural Philosophy, obtaining at twenty-one the degree of M.A. with First Class Honours in Mathematics.

Having gained the Bruce of Grangehill Mathematical Scholarship as well as the Drummond, he became class-assistant to Professor Peter Guthrie Tait, Senior Wrangler, one of the eminent physicists of the nineteenth century. On Tait's recommendation, he was in 1873 appointed Professor of Mathematics in the Imperial College of Engineering, the College having been founded that very year by the Government of Japan. He landed in the Far East on 6th June, accompanied by Dr Henry Dyer, Whitworth Scholar and first Principal of the Institution.

Completing an engagement of five years, Professor Marshall remained in Tokyo, succeeding William E. Ayrton on his retiring from the Chair of Natural Philosophy and Telegraphy in the Imperial College. Ayrton's wife, it may be remembered, was the only woman member of the Institution of Electrical Engineers; she it was who carried out electric-arc experiments and water-motion researches.

On his return to Scotland in 1881, D. H. Marshall assisted his old chief (Tait) for one winter, thereafter obtaining the Professorship of Physics in Queen's University, Canada. He reached Kingston in the autumn of 1882 his companion on the voyage being the Very Rev. George M. Grant, D.D., five years later Principal of Queen's. Marshall resigned the Chair in 1907.

$\mathrm{His}$ recreations are described as "travelling and star-gazing." $\mathrm{He}$ 
enjoyed life to the full; he gloried in his walking powers. He saw the most attractive parts of Japan, speaking the language fluently. Twice he climbed Fujiyama (12,365 feet). Ten days of a Christmas vacation he spent encircling the base of Fuji; the experience has been written in The Land of the Morning by his fellow-traveller, Dr William G. Dixon, Professor of English Literature. Twice also he ascended Asamayama, an active volcano of 8100 feet.

Fond of travel, he sailed round the world no fewer than four times, on one occasion acquiring at Torres Strait a specimen of the Great Clam (Tridacna gigas), the valves weighing $582 \mathrm{lb}$. in all.

Visiting Samoa in September 1894, he called at Vailima. In receiving the former tutor, R. L. S. spoke a few words of welcome, drinking from a wooden bowl, thereafter handing it to the guest. The bowl contained Kava (or Kawa), the beverage which the South Sea Islanders extract from the root of a species of pepper. The sederunt of two hours was interrupted by Mrs Stevenson, who, judging from the hearty laughter, said that her husband had no doubt enjoyed the tête-à-tête, although he seemed to neglect his doctor's orders. The professor was saddened to find the author of Treasure Island a wreck whose end was approaching. Stevenson, it will be recalled, died suddenly three months later, namely, on 3rd December 1894.

From boyhood D. H. Marshall loved astronomy, living to be one of the very few scientists who had observed two transits of the planet Venus.

His intimates mourn a friend warm-hearted and intensely human.

He was elected a Fellow in 1882.

R. T. S. 